\title{
Editorial: Educators behaving badly
}

New Zealand Journal of Teachers' Work, Volume 13, Issue 2, 79-80, 2016

\author{
NESTA DEVINE \& LEON BENADE \\ Co-Editors
}

As 2016 comes to an end, salacious news headlines seem to suggest that an element of the teaching profession will not be able to look back on this year with any degree of pride or satisfaction.

- "Auckland teacher who downloaded porn on school computer busted by students"

- "Teacher helped students cheat and smoked with them"

- "Inappropriate conduct sees Auckland teacher deregistered"

- "Northland teacher deregistered and censured for filming students"

- "Teacher banned for having vodka at school"

- "Auckland teacher stripped of registration after having sex with a pupil"

These headlines evoke a range of responses. One is to excuse this as the behaviour of a tiny segment of an otherwise honourable profession. Another is disgust, shock, even horror, particularly in response to the story carried by The New Zealand Herald, which reported an "Auckland teacher who had sex with a 17-year-old student and let the student watch her have sex with her partner" (Nightingale, 2016). A third response may be to accuse Initial Teacher Education of failing to provide suitable ethical guidance and guidelines to student teachers. Or, it might be charged, unethical conduct is the result of lowered entrance standards to teacher education, and a sign that teaching is increasingly staffed by Gen $Y$ graduates who fail to recognise the ethical nature of their work. More fundamentally, we suggest, questions might also be raised about the quality of mentoring available in the schools these miscreants taught at, particularly if there are repeated incidents involving different people from the same school.

Further thought, however, might yield some more reflective responses: mass education requires a mass workforce, who can be assumed to carry with them the failings of their peers: alcoholism, drug addiction, confusion of sexual desire with the intoxicant of power, and, most interestingly from the policy point of view, a logical if misguided response to the increasing significance to the school and teacher of high test scores-cheating. Cheating is unlikely to be a problem if the focus of the school and teacher is on learning. High stakes testing will always carry with it the motivation to cheat, whether on the level of student, teacher, school, technical institute, university or indeed country.

At another level of the teaching profession, recent news headlines have revealed a different slippage in ethical conduct. To wit, the ill-advised comments of a (now ex-) Chancellor of a prominent New Zealand university regarding the 
differences between male and female veterinary graduates. In response, Paul Little (2016), of The New Zealand Herald, wrote scathingly on the failings of 'pale, male and stale' University Chancellors. The view of the erstwhile Chancellor, Chris Kelly (his rather bewildered and bewildering subsequent apology notwithstanding), is that training women veterinary surgeons is a poor investment because they tend to take time out to have a family: "one woman graduate is equivalent to two-fifths of a fulltime equivalent vet throughout her life because she gets married and has a family, which is normal" (Burke, 2016). The quoted article, in Rural News, conveyed the belief of programme planners that men were more desirable graduates because they were better able to handle large animals, and to find living in the country more acceptable. Little (2016), has put together the change in admission procedure, with a change in first year requirements, to represent a dumbing down of the academic requirements of the course to allow more men, whose grades apparently do not match those of the women, to enter the veterinary school.

Although the ex-Chancellor's views are dated and sexist, he is not, actually, an educator-Chancellor's are generally chosen from the ranks of 'distinguished' members of the community, not from the teaching staff of a university. Of greater concern, from an educational point of view, is that university academic staff have altered their programmes in a way which apparently dovetails with the ex-Chancellor's outdated views, and thus likely share his opinions. They should be called to account. So too, we argue, should the schools that have not created the kind of ethical climate that would render it plain to all who work in those schools that unethical practices have no place in the education profession.

This issue of New Zealand Journal of Teachers' Work continues to provide a platform for work of a critical nature. The articles featured here reflect a critical concern with shortcomings in our education system. They range from the challenges facing special needs students in Innovative Learning Environments, failures to adequately issues surrounding environmental sustainability, the cultural challenges faced by Chinese international students, to structural economic injustices in New Zealand (and global) society.

\section{REFERENCES}

Burke, P. (2016, December 6). Massey to go more practical. Rural News. Retrieved from http://www.ruralnewsgroup.co.nz/item/11200-massey-togo-more-practical

Little, P. (2016, December 18). One less shaky old hand at the tiller. The New Zealand Herald. Retrieved from http://www.nzherald.co.nz/paullittle/news/article.cfm?a id=732\&objectid=11767448

Nightingale, M. (2016, December 19). Teacher at Sir Edmund Hillary Collegiate School in Auckland has sex with student. The New Zealand Herald. Retrieved from http://www.nzherald.co.nz/nz/news/article.cfm?c id=1\&objectid=1176960 $\underline{3}$

The opinions expressed are those of the paper author(s) and not the New Zealand Journal of Teachers' Work. Copyright is held by individual authors but offprints in the published format only may be distributed freely by individuals provided that the source is fully acknowledged. [ISSN-1176-6662] 